\title{
特集 「各種病態における栄養管理・治療の最近の展開」
}

\author{
序文 \\ 各種病態における栄養管理の最近の進歩
}

石 原 寿 光

日本大学医学部内科学系糖尿病代謝内科

\section{Recent Progresses in Nutritional Management in Various Pathophysiological Conditions}

Hisamitsu IsHIHARA

Division of Diabetes and Metabolic Diseases, Department of Internal Medicine, Nihon University School of Medicine

\begin{abstract}
栄養とは, 生命を維持するために養分を摂る営みを指 し，養分の構成要素が栄養素である，生命の維持を劦か す病態に陥った個体を回復させるためには, 個々の病気 の原因を治療していくこととともに, 個体の栄養状態を 病態回復に適切な状態にすることが重要である。また, 健康状態においても, 栄養状態を適正に保つことが, 疾 患の発症予防に不可欠である。

栄養管理の重要性は古くから認識されながら，特に慢 性疾患における科学的な解析は, 遅れてきたように思わ れる。一方, 手術前後の栄養管理は, 比較的短期でその out come が得られることもあり, 活発に検討されてきた.
\end{abstract} 本特集では, 主に慢性疾患や病的状態における栄養管理
の最近の研究の進歩を 6 人の先生方に, 解説していただ いた。まず疾患を発症するリスクが高く，その予防に栄 養管理が重要である, 高齢者と肥満者における栄養管理 について，ご執筆いただいた。続いて，日常遭遇するこ とが多く，栄養管理の重要性が高い肝疾患と腎疾患にお ける現状とその進歩を, 専門の先生方に解説をお願いし た. 最後に, 栄養管理における最近のトピックスとして, 低炭水化物食とやや専門的であるが, カーボカントを利 用した血糖管理の実際を紹介していただいた。臨床医に とって, わかりやすい, 一般的な知識の習得にふさわし い, 特集になっていると思われる. 先生方のお役に立て ていただければ，幸いである。 